begrebet meget bredt, og det omfatter en række hinanden udelukkende fænomener. Dels er begrebet fuldstændig denormativiseret. I en rent beskrivende fremstilling lader det sig gøre, men i en så stærk normativ optik, som Gray arbejder med, bliver resultatet vildt polemisk.

Hans idéhistoriske fremstilling er meget selektiv: hele modernitetsbestemmelsen er bygget op over en bestemt tradition, nemlig positivismen, som i Grays fremstilling ser ud til at have været totaldominerende. Meget, meget store dele af modernitetens idé-traditioner er ganske enkelt negligeret. At modernitetsbegrebet eller idéen har undergået grundlæggende justeringer og ændringer i Vesten synes helt at gå hen over hovedet på Gray. Værre er, at han slet ikke har sans for, at der allerede i udgangspunktet for modernitetstænkningen $i$ Vesten var flere forskellige traditioner, som var på bane. Fx den skotske oplysning, Herder-Hegeltraditionen og Kant. Hans bærende idétradition er alt, alt for selektivt valgt og $\mathrm{i}$ øvrigt alt for homogeniseret.

Som upolemisk og selvstændig udarbejdelse af et modernitetsbegreb er Grays fremstilling ikke meget værd, men som kritik af naive modernitetsforestillinger, går den an. Han har jo ret i, at modernitet ikke kun udmønter sig på en enkelt måde, men han overser, at skønt dette er rigtigt, så er der dog grænser, indenfor hvilke variationen kan forekomme, hvis begrebet om det moderne ikke skal blive til pjat. Hans beskrivelse af $\mathrm{Al}$ Qaeda er af denne art: at Al Qaeda kun er mulig i moderniteten er der nxppe mange, der reelt vil afvise, men herfra til at hævde, som det sker, at $\mathrm{Al}$ Qaeda er moderne, er der langt: hele det normative grundlag omkring autonomi, adskillelse af det offentlige og det private samt ideen om på sekulariseret grundlag at opbygge regler, der skal være alment begrundelige og tilsluttelige i det offentlige rum er jo fraværende. Og det hører med til modernitetsideen. Samme kortslutning som sker omkring Al Qaeda dukker op i Grays bestemmelser af nazisme og stalinisme.

Gray skelner ikke mellem modernisering og modernitet. Det betyder at det reelt bliver teknologien, som bliver grundkriteriet på det moderne. Underligt nok er han her fanget af den positivisme, han så heroisk vil gøre op med.

Ud over det problematiske opgør med modernitetsmyten rummer bogen i strækninger underholdende og informative bemærkninger til moderne økonomisk videnskab, Verdensbanken og IMF. Bogen er godt oversat af Frank Beck Lassen.

Hans-Jorgen Schanz

\footnotetext{
Fra byggehjem til verdensborgerskab

Peter Kemp: Verdensborgeren som padagogisk ideal. Hans Reitzels Forlag, 2005, 312 sider, kr. 299,-
} 
I de senere år er verdensborgeren og kosmopolitisme blevet taget op i den internationale filosofiske og politiske debat. Peter Kemps "Verdensborgeren som pædagogisk ideal" er (sammen med Slagmark nr. 41) en af de få udgivelser der har taget emnet op på dansk. Peter Kemp leverer i bogen en skarp og relevant kritik af det danske uddannelsessystem og særligt folkeskolen, idet han påpeger, at i dagens folkeskole fortrænger lokale ha'-det-rart-værdier alle universelt gyldige værdier (s. 30) - ja skolen er blevet "et hyggehjem for det forudsætningsløse menneske, der opfinder hele verden, sin kultur og sit sociale liv forfra" (s. 33).

Bogen er meget indholdsrig og behandler verdensborgerbegrebet både filosofisk, idéhistorisk og i forhold til aktuelle politiske eksempler. For Kemp er det afgørende, at verdensborgeren bliver sat på dagsordenen i hele uddannelsessystemet. Med andre ord er det bogens formål at bevidstgøre lærere og elever om verdensborgeren - at "vise, hvordan en nutidig pædagogisk hermeneutik kan være kongevejen til livet som både medborger og verdensborger." (s. 12).

Bogen består af tre dele, der bærer titlerne 'Udfordringerne', 'Historien' og 'Opgaven'.

Første del handler om, hvordan den klassiske idé om verdensborgeren kan konkretiseres i dag dvs. i forhold til nutidens globale udfordringer - de udfordringer, der 'nøder os til at tæn- ke som verdensborgere'. Med et udtryk fra den tyske pædagogiske filosof Wolfgang Klafki taler Kemp således om de tre centrale 'epokaltypiske nøgleproblemer', nemlig den finansielle globalisering, konflikterne mellem nationer og kulturer samt truslerne mod miljøet. Det er på høje tid, at disse emner kommer på dagsordenen i det lukkede og selvtilstrækkelige danske uddannelsessystem, hvor fokus sjældent rækker videre end til den enkelte elevs 'ekstremt individualistiske selvdannelse' (s. 33). I denne del behandles bl.a. modsætningen mellem stat og globalisering, og vi kommer omkring aktuelle fænomener som Attac og andre antiglobaliseringsbevægelser eller rettere fortalere fra en solidarisk og human globalisering.

Der er også en interessant diskussion af forholdet mellem verdensborgeren som pxdagogisk ideal og opdragelsen i nationale og kulturelle traditioner. Nationens paradoks, der også gennemsyrer den danske Europadebat, er at den er både for og imod det internationale, der både truer og beskytter den (s. 43). Kemp søger her at vise, hvordan paradokset ikke er en selvmodsigelse men en dobbelthed i nationstanken, der oprindeligt "ikke blev opfattet i modsætning til verdensborgerideen, men blev forstået som verdensborgerens konkrete individualisering" (s. 44). Ligeledes gennemgås nationen som borgerligt projekt (Voltaire, Rousseau) og som kulturel erfaring (Herder). Ifølge Kemp kan den kos- 
mopolitiske filosofis vanskeligheder med modsætningen mellem det partikulære og det universelle overvindes (s. 60) ved at nationerne ophører med at være selvstændige (borgerlige) projekter og i stedet bliver 'nationer $i$ betydningen kulturelle erfaringer af fælles arv og miljø' (s. 57). En europæisk forfatning vil ifølge Kemp være 'et kosmopolitisk bidrag til verdensfreden' (s. 64).

I afsnittet 'Samtalen mellem kulturer' berører Kemp kort emnet multikulturel uddannelse, bl.a. under inddragelse af Martha Nussbaum. Viden om de andre er ikke nok, der må også være forståelse og fortolkning. En uddybning af dette afsnit ville måske have været velkommen blandt de af bogens læsere, der har deres gang i den stadig mere multikulturelle danske folkeskole.

Endelig behandles de aktuelle globale trusler mod miljø og bæredygtighed. Som med kultursammenstødene handler dette ikke kun om viden, men er også et etisk spørgsmål. Det slås fast, at bæredygtighed grundlæggende er et etisk begreb, og de forskellige dimensioner af begrebet gennemgås.

I bogens anden del 'Historien' gennemgås verdensborgerbegrebets (idé-)historie. Kemp fortæller, hvordan den oprindelige, førmoderne verdensborger opstod med den universalisme, der blev muliggjort af rejserne $i$ antikken. Den første, der kaldte sig kosmopolit, er som bekendt Diogenes fra Sinope - ifølge Kemp en ekstrem individualist, der ønskede sig fri af alle bystatens materielle og sociale bånd. Hos stoikerne blev verdensborgerbegrebet forbundet med menneskeslægtens fællesskab, men det var stadig af rent personlig karakter uden den store politiske betydning. Historien bevæger sig videre over den kristne verdensborger og frem til oplysningstiden, hvor verdensborgeridéen vendte stærkt tilbage. Kant var den centrale fortaler, og Kemp placerer verdensborgeren i sammenhæng med Kants øvrige filosofi. Det afgørende bidrag til verdensborgerideen ligger i Kants udvikling af folkeretten som retsfilosofisk forstadium til verdensborgerretten. Kants moderne verdensborger er med andre ord forudsætning for den globale verdensborger, der aktuelt er brug for, hvis de globale tidstypiske nøglespørgsmål, der er emnet for bogens første del, skal løses.

Sidste del af bogen 'Opgaven' er viet til den pædagogiske filosofi, idet det er gennem denne, at verdensborgeren skal realiseres som ideal i uddannelsessystemet. Bl.a. gennemgås dannelsesbegrebets idéhistorie fra Herders Bildung der Humanität og frem til begrebets aktuelle renæssance, og spændingen mellem dannelse og uddannelse samt begreber som livslang læring diskuteres. Der er ingen dannelse uden en idéhistorie, som den enkelte overtager, og således har hermeneutikken en fremtrædende plads i denne del af bogen: "Som etik eller vision om det gode liv er 
den pædagogiske praksis genstand for en reflekterende hermeneutik, der selv er etik eller udfolder en etik. [...] Den pædagogiske filosofi er således kunsten at kunne forstå, udvikle og formulere den pædagogiske kunst i forhold til sin egen tid." (s. 196)

Det er vigtigt for Kemp at rehabilitere begrebet om mimesis, der er 'hemmeligheden ved pædagogisk formidling'. Han taler imod tidens mantra om elevens selvdannelse på egne præmisser. Mimesis er kommet i miskredit pga. frygt for ensretning og indoktrinering, men mimesis skal ikke blot være efterlignende, men også skabende. Her er Ricæur en central inspirationskilde.

Ifølge Kemp må pædagogisk filosofi være 'filosofisk hermeneutik med verdensborgerlig hensigt'. Den pædagogiske filosofi er som nævnt kongevejen til at få løst påtrængende aktuelle problemer. Efter endt læsning af bogen kan man imidlertid spørge, $\mathrm{i}$ hvilken grad viden om pædagogisk filosofi som hermeneutik er afgørende for en øget verdensborgerlig bevidstgørelse i fx folkeskolen. Bogens aktuelle indslag (om Attac, Irak-krigen, Foghs udfald mod smagsdommere og rundkredspædagogik) er både dens styrke og svaghed. Denne anmelder finder det velgørende med tydelige holdninger og med aktuelle begivenheder, der indsættes $i$ en filosofisk sammenhæng, mens andre måske vil mene, at disse afsnit hurtigt bliver uaktuelle og mindre relevante.

Det samme med de filosofiske af- snit. De kan forekomme tunge og ukonkrete (for en skolelærer fx, og sikkert også for mange seminarielærere), men igen kommer det an på læserens behov. Nogle ville måske efterlyse en strammere redigering af bogen, men som Kemp selv er inde på i forordet, har han snarere prioriteret at få bogen ud og verdensborgeren på dagsordenen. Et alternativ kunne have været en klarere læservejledning, der fortæller hvilke afsnit, der henvender sig til hvilke grupper af læsere. Det ville måske lette vejen til den mere praktiske realisering af en pædagogik med verdensborgerlig hensigt. Endelig skal det fremhæves, at bogen har et godt emne- og navneregister, hvilket kan være til stor hjælp for læseren af denne vigtige, men sine steder svært tilgængelige bog.

Gro Hellesdatter Jacobsen

\section{Modernitetens lidelsesfyldte liv}

Anders Draby Sorensen og Hans Jorgen Thomsen (red.): Det svare liv. Om lidelsen $i$ den moderne kultur. Aarbus Universitetsforlag, 2005, 271 sider, kr. 248,-

Det er muligt, at psykoanalysen og dens ophavsmand Sigmund Freud ikke længere spiller nogen priviligeret rolle $\mathrm{i}$ den aktuelle psykologiske forskning, hvor nyere teorier synes at have overtaget og levere mere plausible forklaringer på psykens beskaffenhed. Inden for humaniora, måske 